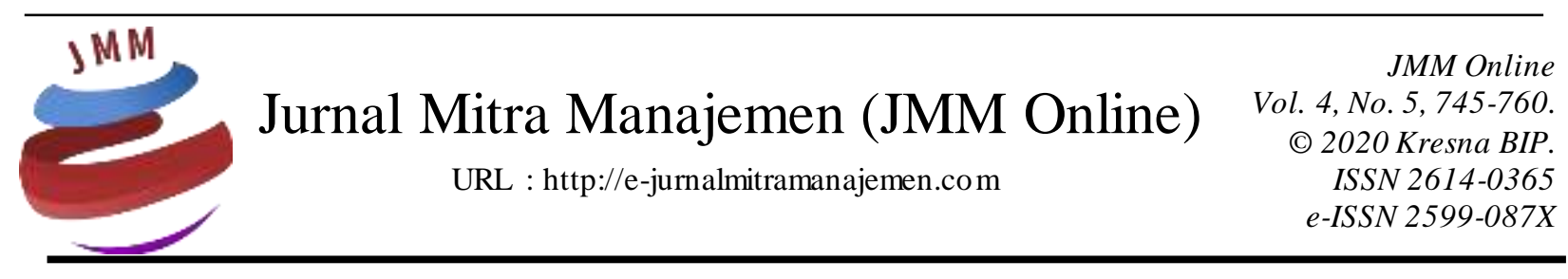

\title{
PENGARUH BUDAYA ORGANISASI DAN TRANSFORMASIONAL LEADERSHIP TERHADAP KINERJA MELALUI KEPUASAN KERJA PEGAWAI BAPPEDA BOJONEGORO
}

\author{
Kustaji 1), C. Sri Hartati ${ }^{2)}$, Soenarmi ${ }^{3)}$ \\ Pascasarjana Universitas Wijaya Putra
}

INFORMASI ARTIKEL

Dikirim : 01 Mei 2020

Revisi pertama : 07 Mei 2020

Diterima : 13 Mei 2020

Tersedia online : 20 Mei 2020

Kata Kunci: Budaya Organisasi, Transformasional Leadership, Kepuasan Kerja, Kinerja Pegawai

Email :fasta_tj@yahoo.com

\section{ABSTRAK}

Penelitian ini bertujuan untuk mendiskripsikan budaya organisasi, transformasional leadership, kinerja pegawai dan kepuasan kerja di Bappeda Bojonegoro. Untuk menganalisis pengaruh budaya organisasi dan transformasional leadership terhadap kepuasan kerja. Untuk menganalisis pengaruh secara langsung budaya organisasi, transformasional leadership, dan kepuasan kerja terhadap kinerja pegawai. Untuk menganalisis pengaruh tidak langsung budaya organisasi dan transformasional leadership terhadap kinerja pegawai melalui kepuasan di Bappeda Bojonegoro.

Penelitian ini berjenis explanatory research dan berpendekatan kuantitatif. Populasi adalah seluruh pegawai Bappeda Bojonegoro dengan jumlah pegawai sebanyak 34 orang. Sampel pada penelitian ini adalah sebesar 34 orang. Teknik sampling menggunakan total sampling. Teknik analisis data yang digunakan adalah path analysis (analisisjalur).

Hasil penelitian ini menunjukan bahwa, budaya organisasi dalam kondisi cukup baik, transformasional leadership, kepuasan kerja, dan kinerja pegawai dalam kondisi baik. Budaya Organisasi dan Transformasional leadership memiliki pengaruh yang signifikan terhadap kepuasan kerja. Budaya organisasi tidak memiliki pengaruh yang signifikan terhadap kinerja pegawai. Transformasional leadership dan Kepuasan kerja memiliki pengaruh yang signifikan terhadap kinerja pegawai. Budaya Organisasi tidak memiliki pengaruh yang signifikan terhadap kinerja pegawai melalui kepuasan kerja. Transformasional leadership memiliki pengaruh yang signifikan terhadap kinerja pegawai melalui kepuasan kerja. 


\section{PENDAHULUAN \\ Latar Belakang}

Tujuan Bappeda Bojonegoro tidak mungkin terwujud tanpa peran pegawai meskipun dukungan sarana dan prasarana serta sumber dana yang dimiliki organisasi tidak akan ada manfaatnya, jika peran aktif pegawai tidak diikutsertakan. Hal ini menunjukkan bahwa sumber daya manusia merupakan kunci pokok yang harus diperhatikan dengan segala kebutuhannya. Pengelolaan sumber daya terkait dan mempengaruhi kinerja organisasional dengan cara meningkatkan kinerja sumber daya manusia yang berkaitan dengan praktek manajemen dan sasarannya cukup luas.

Pola kinerja pegawai harus diperhatikan sehingga terjalin hubungan yang sinergis. Gibson dalam Megantara, dkk.. (2019) menyatakan ada 3 faktor yang berpengaruh terhadap kinerja. Faktor pertama adalah faktor individu, seperti kemampuan, ketrampilan, latar belakang keluarga, pengalaman kerja, tingkat sosial, dan demografi seseorang. Kedua adalah faktor psokologis, seperti presepsi, peran, kepribadian, motivasi dan kepuasan kerja. Faktor ketiga adalah faktor organisasi, seperti struktur organisasi, desain pekerjaan, kepemimpinan dan sistem penghargaan. Faktor psikologis, kepuasan kerja dan faktor organisasi seperti budaya organisasi, akan berpengaruh terhadap kinerja.

Dalam meningkatkan kinerja pegawai, kepuasan kerja pegawai dalam bekerja harus mendapat perhatian dan pemenuhan hal ini terutama menjadi tugas pimpinan organisasi. Bagi pegawai, kepuasan kerja merupakan faktor individu dan sarana untuk mencapai produktivitas kerja. Jadi dalam lingkup manajemen sumber daya manusia, faktor kepuasan kerja memberikan manfaat baik bagi organisasi/organisasi, pegawai, bahkan bagi masyarakat.

Kepuasan kerja bagi seorang pegawai merupakan faktor yang amat penting karena kepuasan yang diperolehnya akan turut menentukan sikap positif terhadap pekerjaan. Perasaan puas dalam bekerja dapat menimbulkan dampak positif terhadap perilaku, seperti misalnya tingkat kedisiplinan dan semangat kerja yang cenderung meningkat. Kepuasan kerja juga berhubungan dengan outcomes seperti kinerja, sehingga apabila kepuasan kerja semakin tinggi maka akan menimbulkan semangat dalam bekerja. Dengan demikian seseorang akan lebih mudah mencapai tingginya kinerja. Penelitian yang dilakukan oleh Utomo, Kabul Wahyu. (2012) menjelaskan bahwa kepuasan kerja berpengaruh signikan terhadap kinerja pegawai CV. Bukit Sanomas, namun hasil penelitian Wijaya tidak sejalan dengan penelitian yang dilakukan oleh Abidin (2015) bahwa kepuasan kerja tidak berpengaruh signifikan terhadap kinerja pegawai di lingkungan kantor wilayah Departemen Agama Provinsi Jawa Tengah. Berdasarkan kedua selisih pendapat tersebut maka dapat disimpulkan bahwa kepuasan kerja dapat mempengaruhi atau tidak tergantung dari indikator yang digunakan sebagai penentu mengenai kepuasan kerja tersebut.

Tingkat kinerja pegawai juga cenderung dipengaruhi oleh budaya organisasi yang berlaku (Gibson dalam Megantara, dkk.. 2019). Budaya amat berpengaruh pada kinerja jangka panjang organisasi. Budaya yang ada pada suatu organisasi menyebabkan para pekerja memiliki cara pandang yang sama dalam melaksanakan aktivitas pekerjaan. Budaya berhubungan dengan bagaimana organisasi membangun komitmen mewujudkan visi, memenangkan hati pelanggan, memenangkan persaingan 
dan membangun kekuatan organisasi (Mangkusasono dalam Wibowo 2016). Menurut Wibowo (2016) budaya organisasi dapat mempengaruhi kinerja sumber daya manusia, dampak budaya organisasi memberikan kontribusi secara langsung pada kinerja pegawai dalam menyelesaikan tugas-tugas yang telah dibebankan. Namun hal ini tidak sejalan dengan penelitian yang dilakukan oleh Sedarmayanti. (2016.) yang menjelaskan bahwa secara parsial, budaya organisasi tidak berpengaruh signifikan terhadap kinerja pegawai Dinas Lingkungan Hidup Kabupaten Boyolali. Berdasarkan kedua hasil tersebut maka terdapat perbedaan yaitu budaya organisasi dapat mempengaruhi kinerja pegawai dan hasil lain mengatakan tidak. Jika dilihat dari keduanya maka dapat dilihat bahwa budaya organisasi memiliki indikator yang berbeda antar kedua peneliti tersebut sehingga hasil yang didapatkan juga berbeda.

Budaya organisasi berkaitan dengan karakteristik budaya suatu organisasi yang harus diikuti pegawai dalam sebuah organisasi tersebut terlepas pegawai menyukai ata tidaknya budaya tersebut. Budaya organisasi dipengaruhi oleh pemilik organisasi. Identitas organisasi dapat ditinjau dari budaya organisasi itu sendiri. Mengenai budaya organisasi dalam sebuah organisasi tidak akan berkembang menjadi organisasi yang maju tanpa memperkokoh fondasi budayanya, setelah budaya kuat maka akan berpengaruh besar terhadap strategi yang dijalankan untuk mencapai tujuan yang telah ditetapkan. Budaya organisasi akan mempengaruhi kinerja pegawai yang dapat manaikkan koordinasi antar pegawai.

Budaya yang kuat dalam organisasi memberikan dorongan kepada anggotanya untuk bertindak dan berperilaku sesuai dengan yang diharapkan organisasi. Dengan mematuhi aturan dan juga kebijakan-kebijakan yang ada di dalam organisasi tersebut diharapkan dapat mengoptimalkan kinerja dan produktivitas para pegawai untuk mencapai tujuan. Budaya organisasi dalam setiap organisasi atau organisasi muncul dari hasil perjalanan hidup para pendiri organisasi atau anggota dari organisasi tersebut. Mereka berperan dalam pengambilan keputusan dan penentu arah strategi organisasi. Hal inilah yang membuat budaya dalam satu organisasi berbeda dengan budaya di organisasi lainnya. Pendapat ini diperkuat oleh pernyataan Robbins (2015) yang mendefinisikan budaya organisasi (organizational culture) sebagai suatu sistem 5 makna bersama yang dianut oleh anggota-anggota yang membedakan organisasi tersebut dengan organisasi yang lain

Hasil penelitian H. M. Thamrin (2014) yang meneliti tentang pengaruh kepemimpinan transformasional dan komitmen organisasi terhadap kepuasan kerja dan kinerja pegawai. Hasilnya menunjukkan bahwa: 1) kepemimpinan transformasional memiliki pengaruh signifikan dan positif terhadap komitmen organisasi, 2) kepemimpinan transformasional memiliki pengaruh signifikan dan positif terhadap kinerja pegawai, 3) kepemimpinan transformasional memiliki pengaruh signifikan dan positif terhadap kepuasan kerja, 4) komitmen organisasi memiliki pengaruh signifikan dan positif terhadap kepuasan kerja dan kinerja pegawai, 5) kepuasan kerja memiliki pengaruh signifikan dan positif terhadap kinerja pegawai. Berbeda dengan hasil penelitian yang dilakukan oleh Purnama, dkk. (2019) dalam hasil penelitiannya menyatakan bahwa gaya kepemimpinan tidak berpengaruh signifikan terhadap kepuasan kerja karyawan, di Perguruan Tinggi Pelita Indonesia Pekanbaru. 


\section{Rumusan Masalah}

Berdasarkan penjelasan latar belakang tersebut maka rumusan masalah penelitian ini adalah :

1. Bagaimana deskripsi budaya organisasi, transformasional leadership, kinerja pegawai dan kepuasan kerja di Bappeda Bojonegoro?

2. Apakah budaya organisasi berpengaruh signifikan terhadap kepuasan kerja pegawai di Bappeda Bojonegoro?

3. Apakah transformasional leadership berpengaruh signifikan terhadap kepuasan kerja pegawai di Bappeda Bojonegoro?

4. Apakah secara langsung budaya organisasi berpengaruh signifikan terhadap kinerja pegawai di Bappeda Bojonegoro?

5. Apakah secara langsung transformasional leadership berpengaruh signifikan terhadap kinerja pegawai di Bappeda Bojonegoro?

6. Apakah kepuasan berpengaruh signifikan terhadap kinerja pegawai di Bappeda Bojonegoro?

7. Apakah secara tidak langsung budaya organisasi berpengaruh signifikan terhadap kinerja pegawai melalui kepuasan di Bappeda Bojonegoro?

8. Apakah secara tidak langsung transformasional leadership berpengaruh signifikan terhadap kinerja pegawai melalui kepuasan di Bappeda Bojonegoro?

\section{Tujuan Penelitian}

Berdasarkan pada rumusan masalah, maka tujuan penelitian ini adalah :

1. Untuk mendeskripsikan budaya organisasi, transformasional leadership, kinerja pegawai dan Kepuasan Kerja di Bappeda Bojonegoro

2. Untuk menganalisis pengaruh budaya organisasi terhadap kepuasan kerja pegawai di Bappeda Bojonegoro

3. Untuk menganalisis pengaruh transformasional leadership terhadap kepuasan kerja pegawai di Bappeda Bojonegoro

4. Untuk menganalisis pengaruh secara langsung budaya organisasi terhadap kinerja pegawai di Bappeda Bojonegoro

5. Untuk menganalisis pengaruh secara langsung transformasional leadership terhadap kinerja pegawai di Bappeda Bojonegoro

6. Untuk menganalisis pengaruh kepuasan terhadap kinerja pegawai di Bappeda Bojonegoro

7. Untuk menganalisis pengaruh tidak langsung budaya organisasi terhadap kinerja pegawai melalui kepuasan di Bappeda Bojonegoro.

8. Untuk menganalisis pengaruh tidak langsung transformasional leadership terhadap kinerja pegawai melalui kepuasan di Bappeda Bojonegoro. 


\section{Manfaat Penelitian}

Manfaat penelitian ini terbagi dua, yaitu manfaat secara teoritis dan manfaat secara praktis.

1. Manfaat Teoritis

Manfaat teoritis penelitian ini adalah :

a. Dapat memberikan kontribusi terhadap perkembangan ilmu manajemen pada umumnya dan manajemen bidang sumber daya manusia pada khususnya.

b. Dapat digunakan sebagai kajian lebih lanjut bagi peneliti lain yang sejenis membahas tentang kinerja pegawai yang dipengaruhi oleh kepuasan kerja, budaya organisasi, transformasional leadership.

2. Manfaat Praktis

Manfaat ptaktis penelitian ini adalah :

a. Bappeda Bojonegoro

Dapat digunakan sebagai masukan informasi kepada Pimpinan Bappeda Bojonegoro dalam penentuan kebijakan yang berkaitan dengan budaya organisasi dan transformasional leadership serta pengaruhnya terhadap kinerja pegawai melalui kepuasan kerja pegawai.

b. Universitas Wijaya Putra

Penelitian ini diharapkan dapat menjadi bahan pertimbangan bagi ilmu manajemen sumberdaya manusia, untuk penelitian selanjutnya.

c. Masyarakat

Penelitian ini diharapkan dapat memberikan kontribusi dalam pengembangan teori mengenai faktor-faktor yang mempengaruhi kinerja pegawai, bagi yang ingin melanjutkan penelitian ini.

\section{KAJIAN PUSTAKA}

\section{Pengertian Kinerja}

Menurut Mahmudi (2015:17) Kinerja merupakan suatu hasil kerja yang dapat dicapai oleh seseorang atau kelompok orang dalam suatu organisasi, sesuai dengan wewenang dan tanggung jawab masing-masing, dalam rangka mencapai tujuan organisasi bersangkutan secara legal, tidak melanggar hukum dan sesuai dengan moral dan etika. Menurut Campbell dalam Darso (2016:32) menyatakan bahwa hubungan fungsional antara kinerja dengan atribut kinerja dipengaruhi oleh tiga faktor, yaitu knowledge, skill, dan motivasi. Kinerja pegawai secara objektif dan akurat dapat dievaluasi melalui tolak ukur tingkat kinerja.

\section{Kepuasan Kerja}

Kepuasan kerja merupakan kondisi ideal yang harus dicapai. Menurut Robbins (2015:36) kepuasan kerja adalah suatu sikap umum seorang individu terhadap pekerjaanya. Menurut Handoko (2015:71) kepuasan kerja adalah keadaan emosional yang menyenangkan atau tidak menyenangkan dengan mana para pegawai memandang pekerjaan mereka. Khaerul dalam Handoko (2015:75) kepuasan kerja merupakan sikap (positif) tenaga kerja terhadap pekerjaannya, yang timbul berdasarkan penilaian terhadap situasi kerja. Penilaian tersebut dapat dilakukan terhadap salah satu pekerjaannya. Berdasarkan beberapa pendapat tersebut dapat disimpulkan bahwa 
kepuasan kerja adalah keadaan emosional seseorang yang bisa terlihat melalui tingkah laku, dan sikap baik yang menyenangkan atau tidak menyenangkan terhadap pekerjaan mereka yang mereka lakukan.

\section{Budaya Organisasi}

Menurut Robbins (2015:256) mendefinisikan budaya organisasi sebagai sebuah sistem makna (persepsi) bersama yang dianut oleh anggota-anggota organisasi, yang membedakan organisasi tersebut dengan oganisasi lainnya. Luthans (2014:85) mengartikan budaya organisasi sebagai pola pemikiran dasar yang diajarkan kepada personel baru sebagai cara untuk merasakan, berpikir, dan bertindak benar dari hari ke hari. Davis dalam Oktaviani (2017) mengartikan budaya organisasi sebagai pola keyakinan dan nilai-nilai (values) organisasi yang dipahami, dijiwai, dan dipraktikkan oleh organisasi sehingga pola tersebut memberikan arti tersendiri dan menjadi dasar aturan berperilaku dalam organisasi.

\section{Kepemimpinan Transformasional}

Menurut Bass dalam buku Yukl (2015:127) menjelaskan bahwa kepemimpinan transformasional adalah suatu keadaan dimana para pengikut dari seorang pemimpin transformasional merasa adanya kepercayaan, kekaguman, kesetiaan, dan hormat terhadap pemimpin tersebut, dan mereka termotivasi untuk melakukan lebih dari pada yang awalnya diharapkan mereka. Pemimpin tersebut mentransformasi dan memotivasi para pengikut dengan cara membuat mereka lebih sadar mengenai pentingnya hasil - hasil suatu pekerjaan, mendorong mereka untuk lebih mementingkan organisasi atau tim daripada kepentingan diri sendiri, dan mengaktifkan kebutuhan - kebutuhan mereka pada yang lebih tinggi. Tucker dan Lewis dalam Yukl (2015) mendefinisikan kepemimpinan transformasional sebagai pola kepemimpinan yang dapat memotivasi pegawai dengan cara membawa pada cita-cita dan nilai-nilai tinggi untuk mencapai visi misi organisasi yang merupakan dasar untuk membentuk kepercayaan terhadap pimpinan.

\section{METODE PENELITIAN}

\section{Jenis Penelitian dan Pendekatan Penelitian}

Penelitian ini merupakan jenis penelitian penjelasan explanatory research. Pendekatan penelitian ini adalah pendekatan penelitian kuantitatif.

\section{Populasi, Sampel dan Teknik Pengambilan Sampel}

Populasi dalam penelitian ini adalah seluruh pegawai Bappeda Bojonegoro dengan jumlah pegawai sebanyak 34 orang. Sampel pada penelitian ini adalah sebesar 34 orang. Teknik sampling yang digunakan dalam penelitian ini adalah total sampling, dimana semua anggota populasi dijadikan sampel. 


\section{Teknik Pengumpulan Data} antara lain:

Dalam penelitian ini, data dikumpulkan dengan menggunakan beberapa teknik 1. Kuesioner

Teknik pengumpulan data dengan menggunakan daftar pertanyaan (kuesioner) yang diberikan kepada responden yang telah ditetapkan sebagai sampel dalam penelitian ini, untuk memperoleh data tertulis.

\section{Dokumentasi}

Teknik pengumpulan data yang dilakukan dengan mempelajari dokumendokumen yang ada kaitannya dengan penelitian ini. Teknik ini terutama digunakan untuk memperoleh data di Bappeda Bojonegoro.

\section{Teknik Analisis Data}

Teknik analisis data yang digunakan pada penelitian ini adalah path analysis (analisis jalur) merupakan perluasan regresi linier berganda yang digunakan untuk menaksir hubungan kausalitas antara variabel dalam model penelitian yang dibangun berdasarkan landasan teori yang kuat.

\section{HASIL PENELITIAN DAN PEMBAHASAN \\ Hasil Penelitian}

Statistik deskriptif, dimana pengujian ini digunakan untuk menggambarkan suatu data secara statistik. Statistik deskriptif dalam penelitian ini merujuk pada nilai rata-rata (mean) dan simpanan baku (standar deviation), nilai minimum dan maksimum serta dari seluruh variabel dalam penelitian ini yaitu Kinerja pegawai (Y), kepuasan kerja $(\mathrm{Z})$ Budaya organisasi $\left(\mathrm{X}_{1}\right)$, Transformasional leadership $\left(\mathrm{X}_{2}\right)$ sebagaimana ditunjukkan pada tabel dibawah ini.

\section{Tabel 1. Descriptive Statistics}

\begin{tabular}{|l|l|l|l|l|l|}
\hline & N & Minimum & Maximum & Mean & $\begin{array}{c}\text { Std. } \\
\text { Deviation }\end{array}$ \\
\hline Budaya organisasi & 34 & 3.00 & 3.86 & 3.2947 & .23088 \\
\hline $\begin{array}{l}\text { Transformasional } \\
\text { leadership }\end{array}$ & 34 & 3.00 & 4.75 & 4.0662 & .48190 \\
\hline Kepuasan kerja & 34 & 2.80 & 4.60 & 3.9235 & .44317 \\
\hline Kinerja pegawai & 34 & 2.75 & 4.75 & 3.8438 & .41122 \\
\hline Valid N (listwise) & 34 & & & & \\
\hline
\end{tabular}

Sumber: Hasil Penelitian, diolah (2019)

Berdasarkan tabel diatas dapat disimpulkan bahwa variabel Budaya organisasi memiliki nilai mean sebesar 3.2947, variabel Transformasional leadership memiliki nilai mean sebesar 4.0662, variabel kepuasan kerja memiliki nilai mean sebesar 3.9235, adapun juga variabel Kinerja pegawai memiliki nilai mean sebesar 3.8438.

Untuk mengetahui kondisi variabel Kinerja pegawai (Y), kepuasan kerja (Z) Budaya organisasi $\left(\mathrm{X}_{1}\right)$, Transformasional leadership $\left(\mathrm{X}_{2}\right)$ di Bappeda Bojonegoro menggunakan skala likert 1-5, dimana 5: sangat baik, 4: baik, 3: cukup baik, 2: kurang baik, 1: tidak baik. Untuk lebih jelasnya dilihat pada tabel berikut : 
Tabel 2. Pembagian Kelas

\begin{tabular}{|l|l|}
\hline Kelas & Kondisi \\
\hline $1.00 \mathrm{~s} / \mathrm{d} 1.80$ & Tidak baik \\
\hline $1.81 \mathrm{~s} / \mathrm{d} 2.61$ & Kurang baik \\
\hline $2.62 \mathrm{~s} / \mathrm{d} 3.42$ & Cukup baik \\
\hline $3.43 \mathrm{~s} / \mathrm{d} 4.23$ & Baik \\
\hline $4.24 \mathrm{~s} / \mathrm{d} 5.00$ & Sangat baik \\
\hline
\end{tabular}

Sumber: Hasil Penelitian, diolah (2019)

Berdasarkan tabel tersebut diatas variabel Budaya organisasi memiliki nilai mean sebesar 3.2947 dalam kondisi cukup baik, variabel Transformasional leadership memiliki nilai mean sebesar 4.0662 dalam kondisi baik, variabel kepuasan kerja memiliki nilai mean sebesar 3.9235 dalam kondisi baik, begitu juga variabel Kinerja pegawai memiliki nilai mean sebesar 3.8438 dalam kondisi baik.

\section{Pengaruh Budaya Organisasi dan Transformasional Leadership Terhadap Kepuasan Kerja di Bappeda Bojonegoro}

Sesuai dengan teknik analisis yang digunakan yaitu analisis jalur (path analisis) dengan menggunakan SPSS. Berdasarkan hasil analisis jalur pertama, maka sesuai dengan kerangka hubungan antara Budaya organisasi $\left(X_{1}\right)$ dan Transformasional leadership $\left(\mathrm{X}_{2}\right)$ terhadap Kepuasan kerja $(\mathrm{Z})$ di Bappeda Bojonegoro diperoleh hasil analisis pada model summary berikut:

Tabel 3. Hasil Analisis Model Summary Pengaruh Budaya Organisasi dan Transformasional Leadership Terhadap Kinerja

\begin{tabular}{|l|l|l|l|l|}
\hline Model & $\mathrm{R}$ & $\mathrm{R}$ Square & $\begin{array}{l}\text { Adjusted } \mathrm{R} \\
\text { Square }\end{array}$ & $\begin{array}{l}\text { Std. Error of the } \\
\text { Estimate }\end{array}$ \\
\hline 1 & $0.557^{\mathrm{a}}$ & 0.311 & 0.266 & 0.37964 \\
\hline
\end{tabular}

Sumber: Hasil Penelitian, diolah (2019)

Berdasarkan pada tabel tersebut dapat diketahui nilai $\mathrm{R}$ Square yaitu sebesar 0.311 yang berarti bahwa $31.1 \%$ Kepuasan kerja dapat dijelaskan oleh Budaya organisasi dan Transformasional leadership, sedangkan sisanya sebesar $68.9 \%$ dipengaruhi oleh variabel lain.

Selanjutnya untuk mengetahui pengaruh Budaya organisasi $\left(\mathrm{X}_{1}\right)$ dan Transformasional leadership $\left(\mathrm{X}_{2}\right)$ terhadap Kepuasan $(\mathrm{Z})$ di Bappeda Bojonegoro secara parsial dapat dilihat pada tabel sebagai berikut: 
Tabel 4. Hasil Analisis Pengaruh Budaya Organisasi dan Transformasional Leadership Terhadap Kepuasan

\begin{tabular}{|l|l|l|l|l|l|l|}
\hline \multirow{2}{*}{ Model } & \multicolumn{2}{|c|}{$\begin{array}{c}\text { Unstandardized } \\
\text { Coefficients }\end{array}$} & $\begin{array}{l}\text { Standardized } \\
\text { Coefficients }\end{array}$ & \multirow{2}{*}{$\mathrm{t}$} & \multirow{2}{*}{ Sig. } \\
\cline { 3 - 5 } & B & Std. Error & Beta & & \\
\hline \multirow{2}{*}{1} & 1.636 & 1.163 & & 1.406 & .170 \\
\cline { 2 - 7 } & (Constant) & .059 & .288 & .031 & .203 & .840 \\
\cline { 2 - 6 } & $\begin{array}{l}\text { Transformasional } \\
\text { leadership }\end{array}$ & .515 & .138 & .560 & 3.729 & .001 \\
\hline
\end{tabular}

Sumber: Hasil Penelitian, diolah (2019)

Berdasarkan pada tabel tersebut diatas, maka dapat disusun persamaan hasil penelitian sebagai berikut:

$$
Z=0.031 X_{1}+0.560 X_{2}+0.689
$$

Berdasarkan ketentuan tersebut dan hasil analisis pengaruh Budaya organisasi dan Transformasional Leadership terhadap kepuasan kerja yang tersaji pada tabel 4 . Maka hasil uji hipotesis dalam penelitian ini dapat dijelaskan sebagai berikut:

\section{Pengaruh Budaya Organisasi Terhadap Kepuasan}

Pengujian hasil hipotesis pengaruh variabel Budaya organisasi terhadap Kepuasan diperoleh dari nilai Standardized Coefficients Beta yaitu sebesar 0.031 dan nilai $\mathrm{t}$ hitung sebesar 0.203 dengan nilai signifikansi sebesar 0.840 , nilai signifikansi tersebut lebih besar dari $0.05(0.840 \geq 0.05)$. Oleh karena itu hipotesanya adalah Ha ditolak dan Ho diterima, yang artinya bahwa Budaya Organisasi berpengaruh tidak signifikan terhadap Kepuasan kerja di Bappeda Bojonegoro.

Dengan demikian dapat dikatakan bahwa peningkatan dan penurunan kepuasan kerja tidak dapat dipengaruhi oleh Budaya organisasi, dengan besarnya kontribusi variabel Budaya Organisasi terhadap Kepuasan sebesar $0.031^{2}=0.000961$ atau sebesar $0.096 \%$.

\section{Pengaruh Transformasional Leadership terhadap Kepuasan}

Pengujian hasil hipotesis pengaruh variabel Transformasional leadership terhadap Kepuasan diperoleh dari nilai Standardized Coefficients Beta yaitu sebesar 0.560 dan nilai t hitung sebesar 3.729 dengan nilai signifikansi sebesar 0.001 , nilai signifikansi tersebut lebih kecil dari $0.05(0.001 \leq 0.05)$. Oleh karena itu hipotesanya adalah Ha diterima dan Ho ditolak, yang artinya bahwa Transformasional Leadership berpengaruh signifikan terhadap Kepuasan kerja di Bappeda Bojonegoro.

Dengan demikian dapat dikatakan bahwa peningkatan dan penurunan Kepuasan kerja di Bappeda Bojonegoro dapat dipengaruhi oleh Transformasional Leadership, dengan besarnya kontribusi variabel Transformasional Leadership terhadap Kepuasan sebesar $0.560^{2}=0.3136$ atau sebesar $31.36 \%$. 


\section{Pengaruh Secara Langsung Budaya Organisasi, Transformasional Leadership dan} Kepuasan Kerja Terhadap Kinerja Pegawai di Bappeda Bojonegoro

Sesuai dengan teknik analisis yang digunakan yaitu analisis jalur (path analisis) dengan menggunakan SPSS. Berdasarkan hasil analisis jalur pertama, maka sesuai dengan kerangka hubungan antara Budaya organisasi $\left(\mathrm{X}_{1}\right)$, Transformasional Leadership $\left(\mathrm{X}_{2}\right)$ dan kepuasan kerja $(\mathrm{Z})$ terhadap Kinerja pegawai (Y) di Bappeda Bojonegoro diperoleh hasil seperti tersaji dalam tabel berikut:

Tabel 5. Hasil Analisis Model Summary Pengaruh Budaya Organisasi, Transformasional Leadership dan Kepuasan Kerja Terhadap Kinerja Pegawai

\begin{tabular}{|l|l|l|l|l|}
\hline Model & $\mathrm{R}$ & $\mathrm{R}$ Square & $\begin{array}{l}\text { Adjusted } \\
\text { Square }\end{array}$ & $\begin{array}{l}\text { Std. Error of the } \\
\text { Estimate }\end{array}$ \\
\hline 1 & $0.659^{\mathrm{a}}$ & 0.434 & 0.377 & 0.32453 \\
\hline
\end{tabular}

Sumber: Hasil Penelitian, diolah (2019)

Berdasarkan pada tabel tersebut dapat diketahui nilai $\mathrm{R}$ Square yaitu sebesar 0.434 yang berarti bahwa 43.4\% Kinerja pegawai dapat dijelaskan oleh Budaya organisasi, Transformasional leadership dan Kinerja, sedangkan sisanya sebesar $56.6 \%$ dipengaruhi oleh variabel lain.

Selanjutnya untuk mengetahui pengaruh Budaya organisasi $\left(\mathrm{X}_{1}\right)$, Transformasional leadership $\left(\mathrm{X}_{2}\right)$ dan kepuasan kerja $(\mathrm{Z})$ terhadap Kinerja pegawai (Y) di Bappeda Bojonegorodapat dilihat pada tabel sebagai berikut:

Tabel 6. Hasil Analisis Pengaruh Budaya Organisasi, Transformasional Leadership dan Kepuasan Terhadap Kinerja Pegawai

\begin{tabular}{|l|l|l|l|l|l|l|}
\hline \multirow{2}{*}{ Model } & \multicolumn{2}{|l|}{$\begin{array}{l}\text { Unstandardized } \\
\text { Coefficients }\end{array}$} & $\begin{array}{l}\text { Standardized } \\
\text { Coefficients } \\
\text { Beta }\end{array}$ & $\mathrm{t}$ & Sig. \\
\cline { 3 - 8 } & $\mathrm{B}$ & Std. Error & & \\
\hline \multirow{2}{*}{1} & (Constant) & .630 & 1.026 & & 2.614 & .014 \\
\cline { 2 - 7 } & Budaya organisasi & .239 & .247 & .134 & .967 & .341 \\
\cline { 2 - 7 } & $\begin{array}{l}\text { Transformasional } \\
\text { leadership }\end{array}$ & .307 & .142 & .328 & 2.257 & .011 \\
\cline { 2 - 5 } & Kepuasan & .581 & .154 & .626 & 3.784 & .001 \\
\hline
\end{tabular}

Sumber: Hasil Penelitian, diolah (2019)

Berdasarkan pada tabel tersebut, maka persamaan hasil penelitian adalah sebagai berikut:

$$
\mathrm{Y}=0.134 \mathrm{X}_{1}+0.328 \mathrm{X}_{2}+0.626 \mathrm{Z}+0.566
$$

Berdasarkan ketentuan tersebut dan hasil analisis pengaruh Budaya organisasi, Transformasional leadership dan kepuasan kerja terhadap Kinerja pegawai secara parsial yang tersaji pada table 6. Maka pengujian hipotesis dalam penelitian ini dapat dijelaskan sebagai berikut:

\section{Pengaruh Langsung Budaya Organisasi terhadap Kinerja Pegawai}

Pengujian hasil hipotesis pengaruh langsung variabel Budaya organisasi terhadap Kinerja pegawai diperoleh dari nilai Standardized Coefficients Beta yaitu sebesar 0.134 dan nilai t hitung sebesar 0.967 dengan nilai signifikansi sebesar 0.341 , nilai signifikansi tersebut lebih kecil dari $0.05(0.341 \leq 0.05)$. Oleh karena itu 
hipotesanya adalah Ha ditolak dan Ho diterima, yang artinya bahwa Budaya organisasi berpengaruh tidak signifikan terhadap Kinerja pegawai di Bappeda Bojonegoro.

Dengan demikian dapat dikatakan bahwa peningkatan dan penurunan Kinerja pegawai tidak dapat dipengaruhi oleh Budaya Organisasi. Dengan besarnya kontribusi variabel Budaya Organisasi terhadap kepuasan kerja sebesar $0.134^{2}=0.017956$ atau sebesar $1.8 \%$.

\section{Pengaruh Langsung Transformasional Leadership terhadap Kinerja Pegawai}

Pengujian hasil hipotesis pengaruh langsung variabel Transformasional leadership terhadap Kinerja pegawai diperoleh dari nilai Standardized Coefficients Beta yaitu sebesar 0.328 dan nilai t hitung sebesar 2.257 dengan nilai signifikansi sebesar 0.011, nilai signifikansi tersebut lebih kecil dari $0.05(0.011 \leq 0.05)$. Oleh karena itu hipotesanya adalah Ha diterima dan Ho ditolak, yang artinya bahwa Transformasional leadership berpengaruh signifikan terhadap Kinerja pegawai di Bappeda Bojonegoro.

Dengan demikian dapat dikatakan bahwa peningkatan dan penurunan kepuasan kerja dapat dipengaruhi oleh Transformasional leadership. Dengan besarnya kontribusi variabel Transformasional leadership terhadap Kinerja pegawai sebesar $0.328^{2}=$ 0.1075 atau sebesar $10.75 \%$.

\section{Pengaruh Kepuasan Kerja terhadap Kinerja Pegawai}

Pengujian hasil hipotesis pengaruh variabel Kepuasan Kerja terhadap Kinerja pegawai diperoleh dari nilai Standardized Coefficients Beta yaitu sebesar 0.626 dan nilai $\mathrm{t}$ hitung sebesar 3.784 dengan nilai signifikansi sebesar 0.001 , nilai signifikansi tersebut lebih kecil dari $0.05(0.001 \leq 0.05)$. Oleh karena itu hipotesanya adalah Ha diterima dan Ho ditolak, yang artinya bahwa Kepuasan Kerja berpengaruh signifikan terhadap Kinerja pegawai di Bappeda Bojonegoro.

Dengan demikian dapat dikatakan bahwa peningkatan dan penurunan Kinerja pegawai dapat dipengaruhi oleh Kepuasan Kerja dengan besarnya kontribusi variabel Kepuasan Kerja terhadap Kinerja pegawai sebesar $0.626^{2}=0.391876$ atau sebesar $39.18 \%$.

\section{Pengaruh Budaya Organisasi terhadap Kinerja Pegawai melalui Kepuasan Kerja}

Berdasarkan analisis sebelumnya bahwa besarnya kontribusi variabel Budaya organisasi $\left(\mathrm{X}_{1}\right)$ terhadap Kepuasan Kerja $(\mathrm{Z})$ sebesar $0.031^{2}=0.000961$ atau sebesar $0.096 \%$, variabel Budaya organisasi $\left(\mathrm{X}_{1}\right)$ terhadap Kinerja pegawai $(\mathrm{Y})$ yaitu sebesar $0.134^{2}=0.017956$ atau sebesar 1.8\%. dan Kepuasan Kerja $(Z)$ terhadap Kinerja pegawai (Y) sebesar $0.626^{2}=0.391876$ atau sebesar $39.18 \%$. Dengan demikian pengujian hipotesis pengaruh variabel Budaya organisasi $\left(\mathrm{X}_{1}\right)$ terhadap variabel Kinerja pegawai $(\mathrm{Y})$ melalui Kepuasan kerja $(\mathrm{Z})$ yaitu sebesar :

$$
0.134+(0.031 \times 0.626)=0.134+0.019406=0.153406
$$

Berdasarkan perhitungan tersebut pengaruh variabel Budaya organisasi $\left(\mathrm{X}_{1}\right)$ terhadap Kinerja pegawai (Y) melalui kepuasan kerja (Z) yaitu sebesar 0.153406 atau sebesar $15.34 \%$. Kemudian jika dilihat pada jalur pertama Budaya organisasi $\left(\mathrm{X}_{1}\right)$ tidak mempunyai pengaruh yang signifikan terhadap Kepuasan Kerja (Z), dan 
kepuasan kerja (Z) mempunyai pengaruh yang signifikan terhadap Kinerja pegawai $(\mathrm{Y})$, pada jalur kedua Budaya organisasi $\left(\mathrm{X}_{1}\right)$ tidak mempunyai pengaruh yang signifikan terhadap Kinerja pegawai (Y), maka Ha ditolak dan Ho diterima karena baik jalur yang pertama maupun jalur yang kedua tidak berpengaruh signifikan. Dengan demikian dapat dikatakan bahwa Budaya organisasi tidak mempunyai pengaruh yang signifikan terhadap Kinerja pegawai melalui kepuasan kerja.

\section{Pengaruh Transformasional Leadership terhadap Kinerja Pegawai melalui Kepuasan Kerja}

Berdasarkan analisis sebelumnya bahwa besarnya kontribusi variabel Transformasional leadership $\left(\mathrm{X}_{2}\right)$ terhadap Kepuasan Kerja $(\mathrm{Z})$ sebesar $0.560^{2}=$ 0.3136 atau sebesar $31.36 \%$, pada variabel Transformasional leadership $\left(\mathrm{X}_{2}\right)$ terhadap Kinerja pegawai (Y) yaitu sebesar $0.328^{2}=0.107584$ atau sebesar $10.75 \%$ dan Kepuasan Kerja $(\mathrm{Z})$ terhadap Kinerja pegawai $(\mathrm{Y})$ sebesar $0.626^{2}=0.391876$ atau sebesar 39.18\%. Dengan demikian pengujian hipotesis pengaruh variabel Transformasional leadership $\left(\mathrm{X}_{2}\right)$ terhadap variabel kepuasan kerja $(\mathrm{Z})$ melalui Kinerja pegawai (Y), yaitu sebesar :

$$
0.328+(0.560 \times 0.626)=0.328+0.35056=0.67856
$$

Berdasarkan perhitungan tersebut pengaruh variabel Transformasional leadership $\left(\mathrm{X}_{2}\right)$ terhadap Kinerja pegawai $(\mathrm{Y})$ melalui kepuasan kerja $(\mathrm{Z})$ yaitu sebesar 0.67856 atau sebesar $67.856 \%$. Kemudian jika dilihat pada jalur pertama Transformasional leadership $\left(\mathrm{X}_{2}\right)$ mempunyai pengaruh yang signifikan terhadap Kepuasan Kerja (Z) dan pada jalur kedua Transformasional leadership ( $\left.\mathrm{X}_{2}\right)$ juga mempunyai pengaruh yang signifikan terhadap Kinerja pegawai (Y), begitu juga kepuasan kerja (Z) mempunyai pengaruh yang signifikan terhadap Kinerja pegawai (Y), maka Ha diterima dan Ho ditolak karena baik jalur pertama maupun jalur kedua mempunyai pengaruh yang signifikan. Dengan demikian dapat dikatakan bahwa Transformasional leadership mempunyai pengaruh yang signifikan terhadap Kinerja pegawai melalui kepuasan kerja.

\section{Pembahasan}

Berdasarkan dari hasil analisis yang dilakukan pada deskripsi variabel Budaya Organisasi dalam kondisi cukup baik, variabel Transformasional leadership dalam kondisi baik, variabel lingkungan kerja dalam kondisi baik, variabel Kinerja Pegawai pegawai dalam kondisi baik, begitu juga variabel kinerja pegawai dalam kondisi baik.

Berdasarkan pada hasil analisis juga dapat diketahui Budaya Organisasi tidak berpengaruh signifikan terhadap Kepuasan Kerja di Bappeda Bojonegoro. Dengan demikian dapat dikatakan bahwa peningkatan dan penurunan Kepuasan Kerja tidak dapat dipengaruhi oleh Budaya Organisasi. Budaya organisasi dipersepsikan oleh responden bahwa inovasi dan pengambilan resiko, perhatian ke hal yang rinci, orientasi hasil, orientasi orang, orientasi tim, keagresifan serta stabilitas di Bappeda Bojonegoro sudah dinilai cukup baik. Sehingga naik turunnya budaya organisasi tidak mempengaruhi kepuasan kerja pegawai di Bappeda Bojonegoro. Hasil penelitian ini tidak sejalan dengan penelitian yang dilakukan oleh Herawan, dkk (2015) yang menjelaskan bahwa adanya pengaruh yang positif dan signifikan pada factor Budaya 
Organisasi terhadap Kepuasan Kerja Karyawan Pada PT Bank Rakyat Indonesia (Persero), Tbk Kantor Cabang Kota Malang Kawi.

Transformasional Leadership berpengaruh signifikan terhadap Kepuasan Kerja di Bappeda Bojonegoro. Dengan demikian dapat dikatakan bahwa peningkatan dan penurunan Kepuasan Kerja di Bappeda Bojonegoro dapat dipengaruhi oleh Transformasional Leadership. Seorang pemimpin dalam meningkatkan kepuasan kerja bertugas dalam caranya memperlalukan bawahan. Kepuasan kerja sangat tergantung pada perilaku pemimpin terhadap karyawan mereka. Jadi, pemimpin harus memastikan bahwa mereka mengungkapkan perilaku yang dapat diterima oleh bawahan. Pernyataan ini didukung oleh hasil penelitian yang dilakukan oleh Susastra dan Subudi (2016) yang menjelaskan kepemimpinan transformasional memiliki pengaruh langsung terhadap kepuasan kerja.

Budaya Organisasi tidak berpengaruh signifikan terhadap Kinerja Pegawai di Bappeda Bojonegoro. Hal ini dapat disebabkan karena pegawai selalu memperhatikan hal-hal rinci dan bekerja dengan berorientasi pada tim, hasil dan orang, sehingga apabila budaya organisasi sudah dianggap baik oleh pegwai. Dengan demikian dapat dikatakan bahwa peningkatan dan penurunan Kinerja Pegawai petugas tidak dapat dipengaruhi oleh Budaya Organisasi. Secara spesifik, peranan budaya organisasi membantu menciptakan rasa memiliki terhadap organisasi, menciptakan jati diri anggota organisasi, menciptakan keterikatan emosional antara organisasi dan karyawan yang terlibat di dalamnya, membantu menciptakan stabilitas organisasi sebagai sistem sosial dan menemukan pola pedoman perilaku sebagai hasil dari norma-norma kebiasaan yang terbentuk dalam keseharian. Dengan demikian budaya organisasi berpengaruh kuat terhadap perilaku para anggotanya. Namun dalam hal ini budaya organisasi sudah dianggap baik oleh pegawai sehingga naik turunnya budaya organisasi tidak mempengaruhi kinerja pegawai Bappeda Bojonegoro. Penjelasan ini mendukung hasil penelitian yang dilakukan oleh Ernawati (2018) menjelaskan bahwa budaya organisasi memiliki pengaruh terhadap kinerja pegawai pada kantor PT. Telkom di Samarinda.

Transformasional leadership berpengaruh signifikan terhadap Kinerja Pegawai di Bappeda Bojonegoro. Dengan demikian dapat dikatakan bahwa peningkatan dan penurunan Kinerja Pegawai di Bappeda Bojonegoro dapat dipengaruhi oleh Transformasional leadership. Kepemimpinan dapat dikatakan sebagai cara dari seorang pemimpin dalam mengarahkan, mendorong dan mengatur seluruh unsur-unsur didalam kelompok atau perusahaan untuk mencapai suatu tujuan perusahaan yang diinginkan sehingga menghasilkan kinerja karyawan berarti tercapainya hasil kerja seseorang atau karyawan dalam mewujudkan tujuan perusahaan tersebut. Penjelasan ini mendukung Rahim, dkk (2018) yang menjelaskan bahwa Kepemimpinan Transformasional berpengaruh terhadap Kinerja Pegawai PT. PLN (Persero) Wilayah Suluttenggo.

Kepuasan Kerja berpengaruh signifikan terhadap Kinerja Pegawai di Bappeda Bojonegoro. Dengan demikian dapat dikatakan bahwa peningkatan dan penurunan Kinerja Pegawai di Bappeda Bojonegoro dapat dipengaruhi oleh Kepuasan Kerja. Karyawan atau pegawai yang puas dengan apa yang diperolehnya dari perusahaan akan memberikan sesuatu yang lebih untuk perusahaan dan kemudian ia akan berusaha 
memperbaiki kinerjanya sehingga ia pun terus mendapat kepuasan kerja yang kemudian akan menghasilkan hasil kerja yang maksimal. Penjelasan ini mendukung pernyataan Sari dan Susilo (2018) bahwa Kepuasan kerja berpengaruh signifikan terhadap kineja pegawai Pabrik Gula Modjopanggoong Tulungagung.

Budaya organisasi tidak mempunyai pengaruh yang signifikan terhadap Kinerja pegawai melalui kepuasan kerja. Hal ini dikarenakan karena baik jalur yang pertama maupun jalur yang kedua tidak berpengaruh signifikan. Pada jalur pertama Budaya organisasi tidak mempunyai pengaruh yang signifikan terhadap Kepuasan Kerja dan kepuasan kerja mempunyai pengaruh yang signifikan terhadap Kinerja pegawai, pada jalur kedua Budaya organisasi juga tidak mempunyai pengaruh yang signifikan terhadap Kinerja pegawai. Besar pengaruh variabel Budaya organisasi terhadap Kinerja pegawai melalui kepuasan kerja yaitu sebesar 0.153406 atau sebesar $15.34 \%$.

Transformasional leadership mempunyai pengaruh yang signifikan terhadap Kinerja pegawai melalui kepuasan kerja. Hal ini diakrenakan baik jalur pertama maupun jalur kedua mempunyai pengaruh yang signifikan. Pada jalur pertama Transformasional leadership mempunyai pengaruh yang signifikan terhadap Kepuasan Kerja dan pada jalur kedua Transformasional leadership juga mempunyai pengaruh yang signifikan terhadap Kinerja pegawai, begitu juga kepuasan kerja mempunyai pengaruh yang signifikan terhadap Kinerja pegawai. Besar pengaruh variabel Transformasional leadership terhadap Kinerja pegawai melalui kepuasan kerja yaitu sebesar 0.67856 atau sebesar $67.856 \%$.

\section{KESIMPULAN DAN SARAN}

\section{Kesimpulan}

Berdasarkan hasil analisis data dan pembahasan tersebut diatas, maka dapat dapat ditarik kesimpulan sebagai berikut:

1. Budaya Organisasi dalam kondisi cukup baik, variabel Transformasional Leadership dalam kondisi baik, variabel Kepuasan Kerja dalam kondisi baik, begitu juga variabel Kinerja Pegawai dalam kondisi baik.

2. Budaya Organisasi memiliki pengaruh yang signifikan terhadap Kepuasan Kerja di Bappeda Bojonegoro

3. Transformasional Leadership memiliki pengaruh yang signifikan terhadap Kepuasan Kerja di Bappeda Bojonegoro

4. Budaya Organisasi tidak memiliki pengaruh yang signifikan terhadap Kinerja Pegawai di Bappeda Bojonegoro

5. Transformasional Leadership memiliki pengaruh yang signifikan terhadap Kinerja Pegawai di Bappeda Bojonegoro

6. Kepuasan Kerja secara langsung memiliki pengaruh yang signifikan terhadap Kinerja Pegawai di Bappeda Bojonegoro

7. Budaya Organisasi tidak memiliki pengaruh yang signifikan terhadap Kinerja Pegawai melalui Kepuasan Kerja di Bappeda Bojonegoro

8. Transformasional Leadership memiliki pengaruh yang signifikan terhadap Kinerja Pegawai melalui Kepuasan Kerja di Bappeda Bojonegoro 


\section{Saran}

Berdasarkan hasil analisis dan kesimpulan tersebut diatas, maka penulis memberikan beberapa saran sebagai berikut :

1. Perlu adanya peningkatan Transformasional Leadership pada pimpinan Bappeda dengan memperbaiki dan meningkatkan update dan upgrade kepemimpinan dalam mendelegasikan tugas dan tanggungjawab kepada bawahan, karena Transformasional Leadership mempunyai pengaruh yang signifikan untuk meningkatkan Kepuasan Kerja maupun Kinerja Pegawai di Bappeda Bojonegoro.

2. Agar Bappeda Bojonegoro melakukan penelitian terhadap variabel-variabel lain yang dapat meningkatkan Kepuasan Kerja maupun Kinerja Pegawai selain Transformasional Leadership, karena masih ada banyak variabel lain yang mempengaruhi Kepuasan Kerja dan Kinerja pegawai di Bappeda Bojonegoro.

\section{DAFTAR PUSTAKA}

Abidin, Yusuf Zainal. 2015. Metode Penelitian Komunikasi Penelitian Kuantitatif: Teori dan Aplikasi. Bandung: Pustaka Setia.

Darso. 2016. Pengaruh Kompetensi dan Kompensasi terhadap Kinerja pada Badan Kesatuan Bangsa dan Politik Kabupaten Kepulauan Vapen. Tesis : Universitas Terbuka Jakarta

Handoko, T. Hani. 2015. Manajemen Edisi 2. Yogyakarta. BPFE

Hasibuan, Malayu S.P. 2016. Manajemen Sumber Daya Manusia. Jakarta: PT Bumi Aksara.

Luthans, Fred. 2014. Perilaku Organisasi, (Alih Bahasa V.A Yuwono, dkk), Edisi Bahasa Indonesia, Yogyakarta

Mahmudi, 2015, Manajemen Kinerja Sektor Publik, UPP STIM YKPN, Yogyakarta

Megantara, Ilma, Suliyanto, dan Purnomo, Ratno. 2019. Pengaruh Budaya Organisasi dan Rotasi Pekerjaan terhadap Motivasi Kerja untuk Meningkatkan Kinerja Pegawai. Jurnal Ekonomi Bisnis dan Akuntansi (JEBA). Vol 21, No 12019

Oktaviani, Widya Dwi. 2017. Pengaruh Budaya Organisasi terhadap Disiplin Kerja Karyawan Kantor Pusat PT. Kereta Api Indonesia (PERSERO). Journal eProceeding of Management: Vol. 4 No. 1 April 2017 : Universitas Telkom

Purnama, Intan; Nyoto, dan Komara, Asmara Hendra. 2019. Pengaruh Gaya Kepemimpinan, Motivasi Kerja, Dan Lingkungan Kerja Terhadap Kepuasan Kerja Dan Komitmen Organisasi Karyawan Di Perguruan Tinggi Pelita Indonesia Pekanbaru. Jurnal Ilmiah Manajemen Vol 7. No. 2, Juni 2019

Robbins, Stephen. 2015, Perilaku Organisasi, Penerbit Salemba Empat, Jakarta

Sedarmayanti. 2016. Manajemen Sumber Daya Manusia Reformasi Birokasi dan Manajemen Pegawai Negeri Sipil. Cetakan ke-15 (Edisi Revisi). Bandung : PT. Refika Adiatama

Thamrin, 2014, "The Influence Of Transformational Leadership and Organizational Commitment On Job Satisfaction and Employee Performance,'”nternational Journal Of Innovation, Management and Tecnology, Vol. 3, No. 5.

Utomo, Kabul Wahyu. 2012. Kepemimpinan dan Pengaruhnya Terhadap Perilaku Cityzenship (OCB), Kepuasan Kerja dan Perilaku Organisasional (Penelitian 
Empiris pada PEMDA KOTA Kebumen). Jurnal Riset Ekonomi dan Manajemen. Vol 2.

Wibowo, 2016. Manajemen Kinerja, Edisi Kelima, PT.Rajagrafindo Persada Jakarta14240.

Yukl, Gary. 2015. Kepemimpinan Dalam Organisasi. Edisi Ketujuh. Jakarta: Indeks 